\title{
МИШЕНЬ-ОРИЕНТИРОВАННОЕ СОЗДАНИЕ НИЗКОМОЛЕКУЛЯРНЫХ РЕГУЛЯТОРОВ КЛЕТОЧНОГО ЦИКЛА, ЭНЕРГЕТИЧЕСКОГО МЕТАБОЛИЗМА И ВОСПАЛИТЕЛЬНЫХ РЕАКЦИЙ
}

\begin{abstract}
А.В. Гарабаджиу
Санкт-Петербургский государственный технологический институт (технический университет, 190013, Россия, Санкт-Петербург, Московский проспект, д. 26.
\end{abstract}

DOI: 10.19163/MedChemRussia2021-2021-53

E-mail: gar-54@mail.ru

Тематическая платформа исследований ориентирована на регулирование сигнальных каскадов высокого уровня. Она включает в себя модулирование убиквитин - зависимой деградации белков за счет ингибирования E3 лигаз, изучение процесса активации и создание активаторов АМФ-активируемой киназы - ключевого элемента энергетического гомеостаза, и исследование каспазного каскада, продуцирования провоспалительных цитокинов.

Исследованы ингибиторы лигазы MDM2 на основеиндолинонапутем предварительного отбора соединений с помощью компьютерного моделирования и последующего высокоэффективного скрининга.

Проведен виртуальный скрининг диверсифицированных библиотек соединений (до 300 тыс.) и получена сфокусированная библиотека (до 300 соединений). На основе двух созданных клеточных тест-систем выявлена группа соединений-хитов из 8 веществ для последующего испытания на мышах.

Разработаны подходы к активации АМФК путем блокирования функции автоингибиторного домена. В частности, проведено компьютерное моделирование участка автоингибиторного домена, играющего ключевую роль в подавлении киназной активности фермента в нормальных условиях, для которого отсутствовали структурные данные. Полученные результаты, свидетельствовавшие о структурной жесткости данного участка, были подтверждены данными рентгеноструктурного анализа, что в совокупности позволили подтвердить правомерность подобного подхода к активации АМФК.

Получен перспективный активатор АМФК П-22, показавший invivo существенный эффект стимуляции физической деятельности.Впервые определен сайт связывания соединения П-22 с гамма-субъединицей АМФК, что позволило провести виртуальную оптимизацию структуры соединений-лидеров.

Исследованы две основные протеазы - катепсин G и эластаза - которые активируют IL-36 и запускают воспалительный процесс. Определены сайты протеолиза цитокинов IL-36 протеазами катепсин G и эластазой. Это позволило методами компьютерного моделирования из базы более чем 600 тысяч соединений получить ряд активных ингибиторов эластазы, проявляющих эффект в области субмикромолярных концентраций. 